\title{
Heavy Metals Content in Foliar Litter and Branches of Quercus petraea (Matt.) Liebl. and Quercus robur L. Observed at Two ICP Forests Monitoring Plots
}

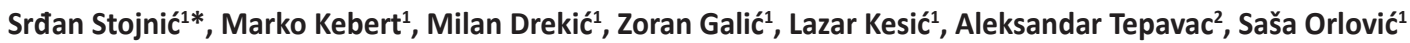

(1) University of Novi Sad, Institute of Lowland Forestry and Environment, Antona Čehova 13d, RS-21000 Novi Sad, Serbia; (2) Public Enterprise "Vojvodinašume”, Preradovićeva 2, RS-21000 Petrovaradin, Serbia

* Correspondence: e-mail: srdjan.stojnic@uns.ac.rs
Citation: STOJNIĆ S, KEBERT M, DREKIĆ $M$, GALIĆ Z, KESIĆ L, TEPAVAC A, ORLOVIĆ S 2019 Heavy Metals Content in Foliar Litter and Branches of Quercus petraea (Matt.) Liebl. and Quercus robur L. Observed at Two ICP Forests Monitoring Plots. Southeast Eur for 10 (2): 151-157. DOI: https:// doi.org/10.15177/seefor.19-11

Received: 17 May 2019; Revised: 24 Jun 2019; Accepted: 5 Jul 2019; Published online: 20 Aug 2019

\begin{abstract}
Background and Purpose: Due to the ability to uptake and accumulate heavy metals (HM) in their aboveground tissues, trees may be used for phytoremediation purposes, but also as bioindicators of environmental pollution. The aims of the present study were: a) to investigate the content and temporal variation of the studied HMs in different plant organs during the period of intensive leaf falling (September-October), in two species from genus Quercus; b) to evaluate the observed HMs content relative to plausible ranges of element concentration in foliar litter, as recommended by ICP Forests Foliar Co-ordinating Centre (IFFCC).

Material and Methods: The contents of zinc $(\mathrm{Zn})$, manganese $(\mathrm{Mn})$, copper $(\mathrm{Cu})$ and iron (Fe) were assessed in the litterfall (i.e. leaves and branches) of Quercus petraea (Matt.) Liebl. and Quercus robur L. grown at two ICP Forests Level II monitoring plots (Fruška Gora and Odžaci, Serbia). Plant material was sampled during September-October 2018 and analyzed by atomic absorption spectrophotometry.

Results: Comparing the content of investigated HMs in foliar litter and branches of Q. robur and Q. petraea, notably higher concentrations of $\mathrm{Mn}$ and Fe have been observed in the foliage of both species, whereas $\mathrm{Zn}$ and $\mathrm{Cu}$ concentrations were higher in collected branch material of both of the above-mentioned tree species. The results further showed that, when compared to plausible ranges of element concentrations in foliar litter, given by IFFCC, average concentrations of Fe and $\mathrm{Zn}$ in the leaves were within suggested limits, whereas certain concentrations of $\mathrm{Mn}$ and $\mathrm{Cu}$ exceeded the proposed ranges. Furthermore, the content of the studied HMs in plant material of both Quercus species significantly varied during sampling period.

Conclusions: Although it was observed that concentrations of certain HMs were beyond plausible limits recommended by IFFCC, our results were in accordance with the findings of other authors who studied HMs content in Quercus species grown in natural forests. For that reason, these limits should be considered optionally, i.e. in the cases when the results significantly deviate from the suggested values. Moreover, we believe that the observed variation in the HMs content during sampling period is related to the sampling procedure commonly applied at ICP Forests monitoring plots, which is indirectly associated with the capacity of trees to accumulate HMs and their phenological properties.
\end{abstract}

Keywords: Quercus robur L., Quercus petraea (Matt.) Liebl., heavy metals content, litterfall

\section{INTRODUCTION}

Recent studies have evidenced that trees can be efficiently used as bioindicators of heavy metals (HMs) contamination in diverse environments, such as urban areas, mining sites, natural forests, etc. [1-4]. Trees are able to uptake HMs throughout their root and leaves and accumulate it in various organs over time [5]. However, due to different uptake and accumulation paths of different HMs in trees, identification of the principal source of accumulated elements is rather 
difficult [6]. For that reason, certain authors believe that for the purpose of air pollution monitoring, lower plants (e.g. mosses and lichens) are more suitable [7, 8]. Nevertheless, using trees for such purpose has a number of advantages. For example, unlike moss and lichens, a clear separation/ distinction among different parts (e.g. leaves, branches, fruit, etc.) is possible in plant species [9]. Leaves usually have large surface area, thus contributing to the removal of airborne inorganic and organic pollutants, which might be either sedimented on the leaf blade or translocated into the leaf [10]. Likewise, as long-lived organisms, trees can reflect the cumulative effect of HMs polluting elements from both soil and ambient air [11]. Finally, the same tree species are widely distributed throughout many countries, thus providing the opportunity for establishing international monitoring networks, such as International Co-operative Programme on Assessment and Monitoring of Air Pollution Effects on Forests (ICP Forests), which enables continent-wide comparison and modeling of data across Europe [12].

Functioning of forest ecosystems largely depends on soil nutrient status, which is, in turn, highly correlated with litterfall amount and its chemical composition, as well as the vicinity of different pollution sources (e.g. highways, mines, etc.). Litterfall has a key role in the global biogeochemical cycles, being an important source of elements (including HMs) and organic matter for soils [13]. Besides macro elements in litterfall, forest production is greatly influenced also by the quantity of micro-components, among which HMs contribute to a large extent [14]. For example, $\mathrm{Fe}, \mathrm{Mn}, \mathrm{Cu}$ and $\mathrm{Zn}$ have been described as essential elements for physiological processes in trees [15]. However, although being reported as important micronutrients for plant growth and development regulations, these elements might be also very toxic in high concentrations [16]. Likewise, excessive amounts of HMs in litterfall can reduce the rate of litter decomposition, thus disturbing biological processes in the soil [17]. For these reasons, one of the principal activities within ICP Forests programme is sampling and analysis of litterfall, due to the importance of litter biomass and its chemical content in cycling processes of elements and organic matter along the forest canopy to the soil and vice versa [13].

In the present paper we studied the content and temporal variation of four HMs ( $\mathrm{Mn}, \mathrm{Fe}, \mathrm{Cu}$ and $\mathrm{Zn}$ ) in litterfall fractions (i.e. leaves and branches) of Quercus petraea (Matt.) Liebl. and Quercus robur L., grown at two ICP Forests monitoring plots, in Serbia. The mentioned oak species are among the most important tree species in Serbia, both from economic and ecological point of view. According to National Forest Inventory of the Republic of Serbia [18], Q. petraea accounts for $5.9 \%$ of volume and $6.1 \%$ of volume increment, being the third most abundant tree species in Serbia (after Fagus sylvatica and Quercus cerris). On the other hand, although it covers only $2.5 \%$ of volume and $1.7 \%$ of increment, $Q$. robur is economically the most valuable tree species in Serbia [19]. The aims of the study were: 1) to investigate the pattern of HMs accumulation in different plant organs, in two species from genus Quercus, 2) to determine the content of HMs in relation to plausible ranges of element concentration in foliar litter, given by ICP Forests Foliar Co-ordinating Centre [13], and 3) to study temporal variation in the concentrations of studied HMs during the period of leaf falling (SeptemberOctober).

\section{MATERIAL AND METHODS}

Plant material was collected from $Q$. petraea and $Q$. robur grown at two ICP Forests Level II monitoring plots situated in Serbia, respectively. The first plot was established in 2009 at Fruška Gora Mountain, in a mixed forest of Quercus petraea, Fagus sylvatica and Tilia platyphyllos, whereas the second plot was founded in 2011, in a pure forest of $Q$. robur on meadow-black soil. Both plots have been founded and maintained by the University of Novi Sad, Institute of Lowland Forestry and Environment (Novi Sad, Serbia). More information about monitoring plots are given in Table 1.

According to ICP Forests manuals [13], 20 fixed litterfall traps have been evenly distributed across the plot to represent the whole area and allow the collection of all tree species plant material. A top height of litterfall traps is approx. $1 \mathrm{~m}$, while the catching area (i.e. the area of trap upper frame) amounts to $0.25 \mathrm{~m}^{2}$. Canopy leaves and other litterfall inputs were collected in nylon nets, $0.5 \mathrm{~m}$ deep, which were attached to trap frames.

Sampling of plant material was performed five times at Fruška Gora and seven times at Odžaci plot during September and October 2018. At both sites, litterfall was collected from each trap (20 per single plot) and pooled in each sampling period, respectively. After collection, plant material was transported to the laboratory and temporarily stored at $4{ }^{\circ} \mathrm{C}$ [13]. Prior to chemical analyses any litter collected was sorted out into foliar and non-foliar fractions (i.e. branches and fruit) and dried at $70^{\circ} \mathrm{C}$ for 24 hours [13].

Determination of selected microelements ( $\mathrm{n} n, \mathrm{Mn}$, $\mathrm{Cu}$ and $\mathrm{Fe}$ ) was done in digested solutions that were made from powdered litterfall samples using standard method of microwave assisted digestion (D series; Milestone, Bergamo, Italy), while the quantification of metals was performed by Atomic Absorption Spectrophotometer in a flame regimen (model FS AAS240/GTA120, Varian - AAS, California, US). Approximately $0.3 \mathrm{~g}$ of oven-dried material were ground and homogenized in a laboratory mill and then digested in $10 \mathrm{ml}$ of nitric acid and $2 \mathrm{ml} \mathrm{30 \%} \mathrm{(w/v)} \mathrm{hydrogen} \mathrm{peroxide} \mathrm{using} \mathrm{a}$ microwave-assisted digestion system (D series; Milestone,

TABLE 1. Description of ICP Forests monitoring plots Fruška Gora and Odžaci.

\begin{tabular}{ccccccc}
\hline Locality & $\begin{array}{c}\text { Latitude } \\
\text { (Deg.Min) }\end{array}$ & $\begin{array}{c}\text { Longitude } \\
\text { (Deg.Min) }\end{array}$ & Altitude (m a.s.I.) & Soil type & $\begin{array}{c}\text { Mean air } \\
\text { temperature }\left({ }^{\circ} \mathrm{C}\right)\end{array}$ & $\begin{array}{c}\text { Annual sum of } \\
\text { precipitations } \\
(\mathrm{mm})\end{array}$ \\
\hline Fruška Gora & $45^{\circ} 09^{\prime}$ & $19^{\circ} 48^{\prime}$ & 490 & Cambisol & 11.2 & 795 \\
Odžaci & $45^{\circ} 27^{\prime}$ & $10^{\circ} 10^{\prime}$ & 86 & Meadow-black & 10.9 & 577 \\
\hline
\end{tabular}


Bergamo, Italy) for $45 \mathrm{~min}$ at $180^{\circ} \mathrm{C}(900 \mathrm{~W})$ [20]. Filtrates were then diluted to $25 \mathrm{ml}$ with deionizer water. Pre-treated samples were processed by AAS using the acetylene/air burner flame technique (with an atomization temperature of about $2300^{\circ} \mathrm{C}$ ). Concentrations of $\mathrm{Zn}, \mathrm{Mn}, \mathrm{Cu}$ and Fe were determined by using single element hollow-cathode lamps at $213.9 \mathrm{~nm}$ (Zn), $324.8 \mathrm{~nm}$ (Cu), $248.3 \mathrm{~nm}$ (Fe) and $279.5 \mathrm{~nm}$ $(\mathrm{Mn})$ respectively, and expressed in $\mu \mathrm{g} \mathrm{g}^{-1} \mathrm{dry}$ weight (d.w.) of plant material.

The data were processed in Statistica 13 software [21], using Analyses of Variance (ANOVA) and methods of descriptive statistics (mean value and standard deviation). Significant differences in concentration of HMs in the leaves and branches of two oak species were determined at $p<0.05$.

\section{RESULTS}

Descriptive statistics of HMs concentrations in Q. petraea and $Q$. robur litterfall from ICP Forests monitoring plots at Fruška Gora and Odžaci are reported in Table 2. Notably higher concentrations of $\mathrm{Mn}$ and Fe have been detected in leaves than in branches of $Q$. petraea and $Q$. robur, respectively. On the other hand, the content of $\mathrm{Zn}$ and $\mathrm{Cu}$ was higher in collected branch material of the above-mentoned tree species.

The ratio between the content of four HMs in leaves and branches, based on the average concentration during the sampling period, is presented in Figure 1 . The highest ratio in the leaves of both species was reached by Fe $(Q$. petraea $=74.2 \%$; $Q$. robur $=74.3 \%)$, which was followed by $\mathrm{Mn}(Q$. petraea $=71.8 \%$; $Q$. robur $=66.7 \%)$. In contrast, slightly higher ratios of $\mathrm{Cu}$ (Q. petraea $=52.1 \%$; Q. robur $=54.3 \%$ ) and $\mathrm{Zn}$ (Q. petraea $=64.1 \%$; $Q$. robur $=56.8 \%$ ) were calculated for branches of the studied tree species.

The results showed that the average detected amount of $\mathrm{Mn}$ in the leaves and branches of $Q$. petraea was $788.6 \mu \mathrm{g} \cdot \mathrm{g}$ ${ }^{1}$ (ranging between 630.7 and $976.8 \mu \mathrm{g} \cdot \mathrm{g}^{-1}$ ) and $309.9 \mu \mathrm{g} \cdot \mathrm{g}$ ${ }^{1}\left(229.4-408.0 \mu \mathrm{g} \cdot \mathrm{g}^{-1}\right)$, respectively (Figure 2). In Q. robur, average concentrations of $\mathrm{Mn}$ were found to be $602.9 \mu \mathrm{g} \cdot \mathrm{g}^{-1}$ $\left(455.1-753.3 \mu \mathrm{g} \cdot \mathrm{g}^{-1}\right)$ and $301.4 \mu \mathrm{g} \cdot \mathrm{g}^{-1}\left(137.2-460.3 \mu \mathrm{g} \cdot \mathrm{g}^{-1}\right)$ in the leaves and branches, respectively (Figure 3 ).

TABLE 2. Average concentration of heavy metals (mean value \pm standard deviation) in litterfall of Quercus petraea (Matt.) Liebl. and Quercus robur L. observed on two ICP Forests monitoring plots.

\begin{tabular}{|c|c|c|c|c|c|c|}
\hline \multirow{2}{*}{$\begin{array}{l}\text { Heavy metal } \\
\text { concentration } \\
\left(\mu \mathrm{g} \cdot \mathrm{g}^{-1}\right)\end{array}$} & \multicolumn{3}{|c|}{ Quercus petraea (Matt.) Liebl. } & \multicolumn{3}{|c|}{ Quercus robur L. } \\
\hline & Leaves & Branches & F-test & Leaves & Branches & F-test \\
\hline $\mathrm{Mn}$ & $788.6 \pm 141.5$ & $309.9 \pm 72.9$ & $45.2^{* * *}$ & $602.9 \pm 110.4$ & $301.4 \pm 116.2$ & $24.8 * * *$ \\
\hline $\mathrm{Fe}$ & $165.2 \pm 24.5$ & $57.4 \pm 21.0$ & $55.7^{* * *}$ & $145.3 \pm 17.5$ & $50.2 \pm 17.5$ & $103.6 * * *$ \\
\hline $\mathrm{Zn}$ & $14.0 \pm 1.7$ & $24.4 \pm 8.8$ & $7.2^{*}$ & $18.9 \pm 2.9$ & $24.8 \pm 3.1$ & $13.9 * *$ \\
\hline
\end{tabular}

* $-\mathrm{p}<0.05 ; * *-\mathrm{p}<0.01 ; * * *-\mathrm{p}<0.001 ; \mathrm{ns}-$ non-significant

Quercus petrea (Matt.) Liebl.

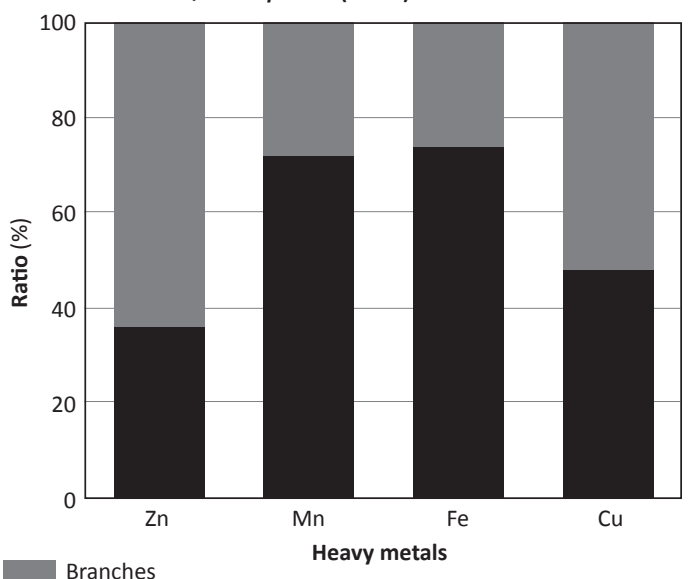

Quercus robur L.

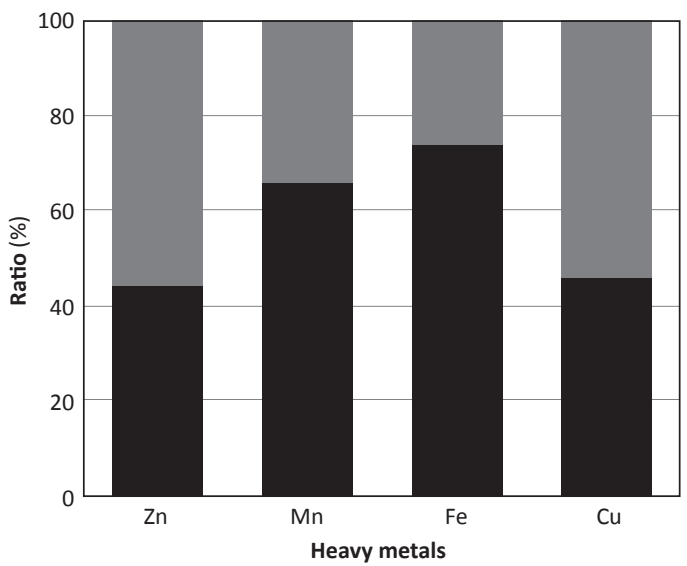

FIGURE 1. The ratio between the content of four heavy metals ( $\mathrm{Zn}, \mathrm{Mn}$, Fe and $\mathrm{Cu}$ ) in the leaves and branches, based on the average concentration $\left(\mu \mathrm{g} \cdot \mathrm{g}^{-1}\right)$ during the sampling period. 

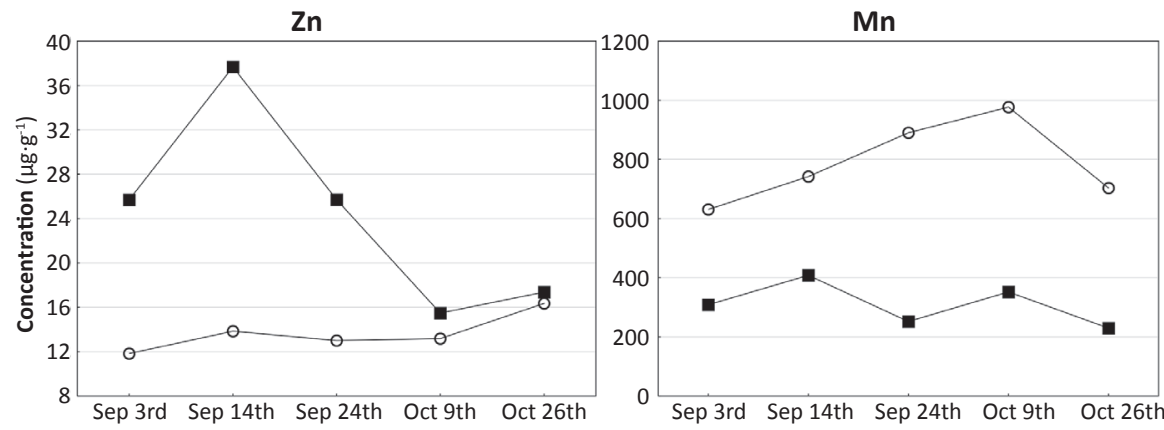

$\mathrm{Cu}$

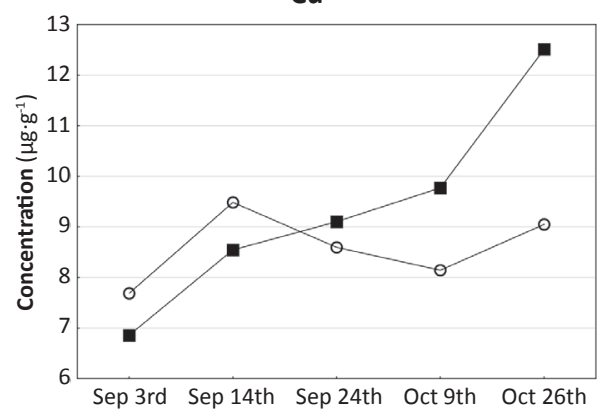

$\mathrm{Fe}$

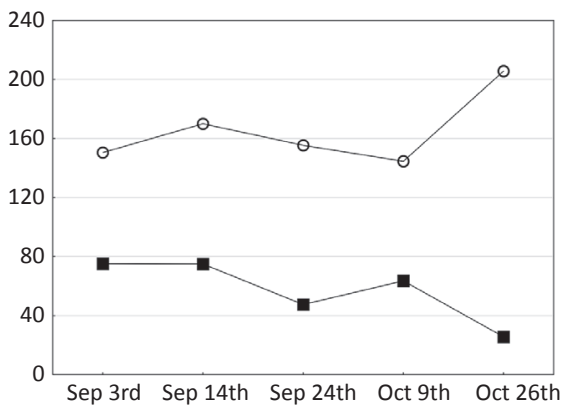

Date of sampling

FIGURE 2. Temporal variation of heavy metals ( $\mathrm{Zn}, \mathrm{Mn}$, Fe and $\mathrm{Cu}$ ) content in the leaves ( $\square$ ) and branches ( $\square$ ) of Quercus petraea (Matt.) Liebl.

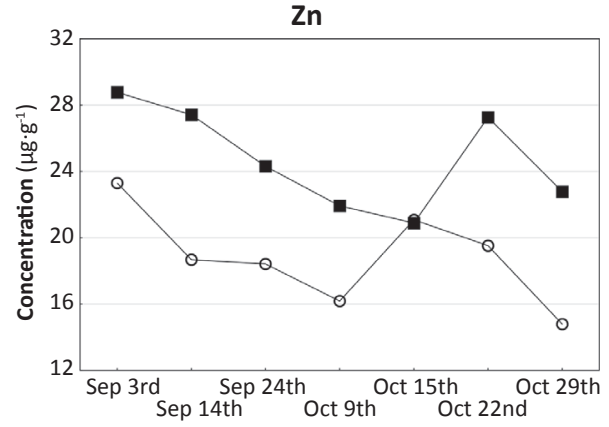

$\mathrm{Cu}$

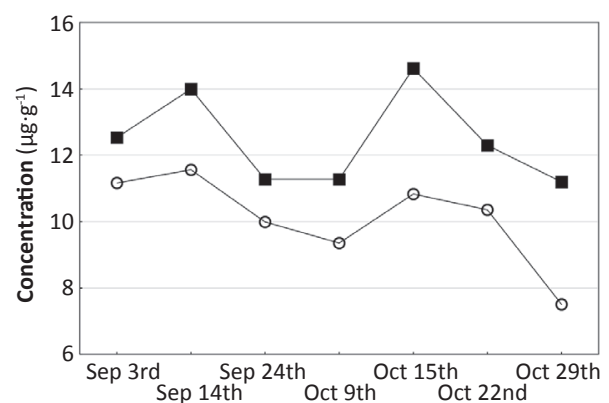

Mn

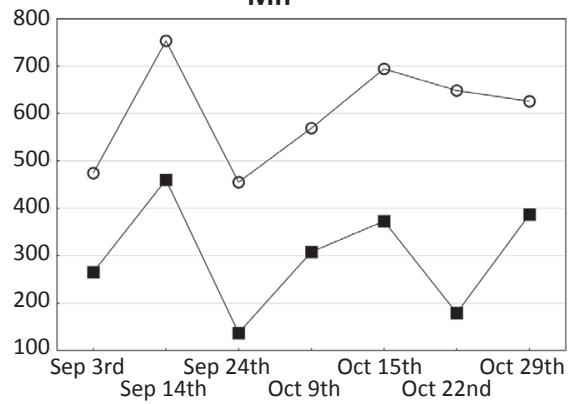

Fe

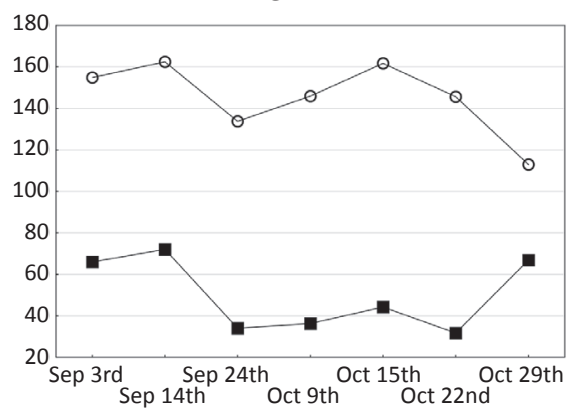

Date of sampling

FIGURE 3. Temporal variation of heavy metals ( $\mathrm{Zn}, \mathrm{Mn}$, Fe and Cu) content in the leaves ( $\square$ ) and branches ( $\square$ ) of Quercus robur L. 
Average detected concentration of $\mathrm{Fe}$ in $\mathrm{Q}$. petraea leaves was $165.2 \mu \mathrm{g} \cdot \mathrm{g}^{-1}$, ranging between 144.5 and 205.6 $\mu \mathrm{g} \cdot \mathrm{g}^{-1}$, while its concentration in branch material was 57.4 $\mu \mathrm{g} \cdot \mathrm{g}^{-1}$ and varied between 25.7 and $75.2 \mu \mathrm{g} \cdot \mathrm{g}^{-1}$. Concerning Q. robur, the observed concentration of $\mathrm{Fe}$ in the leaves and branches was a bit lower than it was recorded in sessile oak and amounted to $145.3 \mu \mathrm{g} \cdot \mathrm{g}^{-1}$ (ranging between 112.9 and $162.5 \mu \mathrm{g} \cdot \mathrm{g}^{-1}$ ) and $50.2 \mu \mathrm{g} \cdot \mathrm{g}^{-1}$ (31.8 and $\left.72.0 \mu \mathrm{g} \cdot \mathrm{g}^{-1}\right)$, respectively.

In contrast to $\mathrm{Mn}$ and $\mathrm{Fe}$, slightly higher content of $\mathrm{Cu}$ was observed in the branch material of both species. In Q. petraea average content of $\mathrm{Cu}$ amounted to $9.4 \mu \mathrm{g} \cdot \mathrm{g}^{-1}$ (ranging between 6.9 and $12.5 \mu \mathrm{g} \cdot \mathrm{g}^{-1}$ ) and $8.6 \mu \mathrm{g} \mathrm{g}^{-1}$ (7.7$\left.9.0 \mu \mathrm{g} \cdot \mathrm{g}^{-1}\right)$, in the branches and leaves, respectively. Similar values for Cu content have been also recorded in $Q$. robur branches $\left(12.0 \mu \mathrm{g} \cdot \mathrm{g}^{-1}\right.$; ranging between $\left.8.3-14.6 \mu \mathrm{g} \cdot \mathrm{g}^{-1}\right)$ and leaves $\left(10.1 \mu \mathrm{g} \cdot \mathrm{g}^{-1}\right.$; ranging between $\left.7.5-11.6 \mu \mathrm{g} \cdot \mathrm{g}^{-1}\right)$.

Average content of $\mathrm{Zn}$ was almost the same in the branches of both tree species; i.e. $24.4 \mu \mathrm{g} \cdot \mathrm{g}^{-1}(17.4-37.7$ $\left.\mu \mathrm{g} \cdot \mathrm{g}^{-1}\right)$ in $Q$. petraea, and $24.8 \mu \mathrm{g} \cdot \mathrm{g}^{-1}\left(21.9-28.8 \mu \mathrm{g} \cdot \mathrm{g}^{-1}\right)$ in $Q$. robur. Finally, $\mathrm{Zn}$ content in the leaf material of $Q$. petraea and $Q$. robur amounted to $13.6 \mu \mathrm{g} \cdot \mathrm{g}^{-1}\left(11.8-16.4 \mu \mathrm{g} \cdot \mathrm{g}^{-1}\right)$ and $18.9 \mu \mathrm{g} \cdot \mathrm{g}^{-1}\left(14.8-23.3 \mu \mathrm{g} \cdot \mathrm{g}^{-1}\right)$, respectively.

\section{DISCUSSION}

Previous studies demonstrated that HMs content within Quercus genus is species- and organ-dependent [22, 23], although environmental conditions [5] and tree lifetime have certain effects on HMs accumulation as well [24]. Since HMs content in two oak species occurring at separated sites and, therefore, growing under different environmental conditions was examined, direct comparison of absolute values of HMs content in their organs was not possible. For that reason, the ratio was used to evaluate accumulation pattern of different HMs in leaves and branches. Similar approach was applied by Węgiel et al. [25] for studying of HMs accumulation in Scots pine stands of different densities. It was found that $\mathrm{HMs}$ content ratio in the leaves and branches of $Q$. petraea and $Q$. robur was similar in both species. Concerning $\mathrm{Mn}$ and Fe notably higher concentrations, and therefore higher ratios of these elements, were recorded in the foliage. Considering the time frame of sample collection (i.e. end of the growing season), the results obtained in this study are in accordance with the findings of Santa Regina et al. [24]. Namely, the authors continually reported seasonal accumulation of these two elements in the leaves of Quercus pyrenaica, whereas only slight increase in accumulation, but not statistically significant, was observed to have occurred in the branches. In contrast, the ratios of $\mathrm{Zn}$ and $\mathrm{Cu}$ were higher in branch material of the studied oak species. Similar results have been reported by Serbula et al. [4], who found slightly higher concentrations of $\mathrm{Zn}$ and $\mathrm{Cu}$ in branches than in leaves of Robinia pseudoacacia trees growing on unpolluted area.

Considering plausible range of element concentrations in foliar litter, given by ICP Forests Foliar Co-ordinating Centre [13], our results evidenced that concentrations of $\mathrm{Fe}$ and $\mathrm{Zn}$ in the studied tree species leaf material were within suggested limits. According to Pitman et al. [13] foliar concentration of Fe should range between 50 and 200 $\mu \mathrm{g} \cdot \mathrm{g}^{-1}$ in $Q$. petraea, and $90-150 \mu \mathrm{g} \cdot \mathrm{g}^{-1}$ in $Q$. robur, which is also confirmed by the results of other authors (e.g. [2628]). Unlike these findings, Aboal et al. [29] and Santamaría and Martin [30] recorded Fe concentration outside the given ranges. In case of $\mathrm{Zn}$, recommended foliage content should vary between 14 and $25 \mu \mathrm{g} \cdot \mathrm{g}^{-1}$ in $Q$. petraea, and $15-25 \mu \mathrm{g} \cdot \mathrm{g}^{-1}$ in $Q$. robur. Similar values have been reported by other authors $[30,31]$, although certain authors reported the content of $\mathrm{Zn}$ in the leaves of studied oak species that was beyond these limits [26, 27, 29].

In contrast to $\mathrm{Fe}$ and $\mathrm{Zn}$, certain concentrations of $\mathrm{Mn}$ and $\mathrm{Cu}$ were outside of plausible limits recommended by Pitman et al. [13]. Namely, while the previously mentioned authors stated that concentration of $\mathrm{Mn}$ in the leaf material should vary between 700 and $1700 \mu \mathrm{g} \cdot \mathrm{g}^{-1}$ for $Q$. petraea, and $1000-1200 \mu \mathrm{g} \cdot \mathrm{g}^{-1}$ for $Q$. robur, our results showed that average concentration of $\mathrm{Mn}$ in the leaves of the latter species was much lower $\left(602.9 \mu \mathrm{g} \cdot \mathrm{g}^{-1}\right)$. Lower values were also reported by other authors: i.e. Kovács et al. [26] and Santamaría and Martin [30] reported that average foliar concentration of $\mathrm{Mn}$ in Q. robur amounted to 817 and 821 $\mu \mathrm{g} \cdot \mathrm{g}^{-1}$, respectively. Likewise, studying $\mathrm{HMs}$ content in the leaves of $Q$. robur trees grown across rural areas of Galicia, Aboal et al. [29] evidenced that average concentration of $\mathrm{Mn}$ was approximately $305 \mu \mathrm{g} \cdot \mathrm{g}^{-1}$. Therefore, it is likely that upper and lower limits should be considered only conditionally. For example, Stanković et al. [32] showed that concentration of $\mathrm{Mn}$ in the leaves of $Q$. petraea varied over a broad range (434.5-722.0 $\left.\mu \mathrm{g} \cdot \mathrm{g}^{-1}\right)$, depending on properties of the growing site. Intriguingly, De Visser [22] observed various foliage concentration of $\mathrm{Mn}$ in three $Q$. robur populations (i.e. 180,420 and $1180 \mu \mathrm{g} \cdot \mathrm{g}^{-1}$, respectively).

Regarding $\mathrm{Cu}$ content in the leaves, slightly higher concentration of this element in case of $Q$. petraea was observed, whereas its concentration in $Q$. robur foliage significantly exceeded the upper limit $\left(7 \mu \mathrm{g} \cdot \mathrm{g}^{-1}\right)$ given by Pitman et al. [13]. Similar results to Pitman et al. [13] have been reported by Kovács et al. [26] and Aboal et al. [29]. On the other hand, Santamaría and Martin [29] have found that average concentration of $\mathrm{Cu}$ in $Q$. robur leaves observed across 14 mixed stands in Spain amounted to $9.8 \mu \mathrm{g} \cdot \mathrm{g}^{-1}$.

Our results showed that the content of all $\mathrm{HMs}$ in litterfall of studied oak species varied between sampling dates, although sampling was performed in a quite short period of time (Figures 2 and 3). Possible explanation for this phenomenon might be the sampling procedure applied at ICP Forests plots. Namely, according to ICP Forests procedures [13], HMs content in plant fractions is estimated from the bulk samples consisting of litterfall collected from all traps on the plot. As sampled litterfall originates from different oak genotypes spanned randomly across the sampling plot area, the results probably depended on both the ability of different genotypes to accumulate HMs in their tissues and the amount of certain genotypes of litterfall collected in the traps. Indeed, previous studies evidenced that HMs content in the plant material may vary over a broad range even among trees within a single population. For example, studying the concentration of $\mathrm{Zn}, \mathrm{Mn}$ and Fe in the leaves of Ulmus laevis Pall. trees, Devetaković et al. [33] reported that 
their contents greatly varied between different trees grown on a small and isolated island. Similarly, studying the content of $\mathrm{Pb}, \mathrm{Mn}, \mathrm{Zn}, \mathrm{Ni}$ and $\mathrm{Fe}$ in different lime genotypes grown across several sites at Fruška Gora Mountain, Šijačić-Nikolić et al. [34] concluded that genotype (i.e. genetic architecture of each sampled tree) was the main driver influencing the concentration of the studied HMs in the leaves (i.e. since metal transporters are genetically coded proteins).

In addition to different capacity of genotypes to accumulate HMs in their tissues, the observed differences in HMs content in litterfall during the sampling period may be also the consequence of phenological characteristics of oak trees on the plots. It is well known that plant phenology depends on a number of factors, such as air temperature, soil moisture, day length, activities of herbivores and pollinators, etc. [35]. Giving an overview of spring and autumn phenology in $Q$. petraea and $Q$. robur at current ICP Forests monitoring plots in the six-year period (2011-2016), Pekeč et al. [36] reported that leaf fall phases may take between 8 and 29 days, depending on tree species and year of observation. However, phenological stages may also be influenced by genotype properties within single tree species [37]. In the case of $Q$. robur the existence of four varieties occurring along Danube and Sava River (precox, typica, tardiflora and tardissima) was even documented, which are distinguished based on spring phenology [38]. In this sense, it might be assumed that phenological phases, and, therefore the intensity of leaf falling in autumn, differ among various trees on the plots, thus contributing to unequal amount of each genotype litterfall in the bulk sample.

\section{CONCLUSIONS}

The results of this study showed that concentrations of $\mathrm{Mn}$ and Fe were significantly higher in the foliage of both oak species, whereas slightly higher content of $\mathrm{Zn}$ and $\mathrm{Cu}$ was observed in the collected branch material. Considering plausible range of element concentrations in foliar litter, suggested by ICP Forests Foliar Co-ordinating Centre [13], it was observed that average concentrations of Fe and $\mathrm{Zn}$ in the leaves were within suggested limits, whereas certain concentrations of $\mathrm{Mn}$ and $\mathrm{Cu}$ were beyond these limits. Nevertheless, our results correspond to the findings of other authors who studied HMs content in natural and unpolluted areas, and therefore we believe that these limits should be considered mainly in the cases when the results significantly deviate from the suggested values. Moreover, it was also observed that the content of HMs in the leaves and branches of the studied tree species varied during the sampling period (September - October 2018), probably as the consequence of sampling procedure commonly applied at ICP Forests monitoring plots, as well as biological characteristics of sampled trees (i.e. the capacity to accumulate HMs and phenological features).

\section{Acknowledgements}

This paper was realized as part of the project "Program praćenja uticaja prekograničnog aerozagađenja u šumskim ekosistemima na teritoriji AP Vojvodine u 2019. godini", financed by the Ministry of Agriculture, Forestry and Water Management of the Republic of Serbia.

\section{REFERENCES}

1. BATOS B, VESELINOVIĆ M, RAKONJAC LJ, MILJKOVIĆ D 2019 Morphological properties of pollen as bioindicators of deciduous woody species in Belgrade parks (Serbia). Topola 203: 19-30

2. ALAHABADI A, EHRAMPOUSH MH, MIRI M, AVAL HE, YOUSEFZADEH S, GHAFFARI HR, AHMADI E, TALEBI P, et al. 2017 A comparative study on capability of different tree species in accumulating heavy metals from soil and ambient air. Chemosphere 172: 459-467. DOI: https://doi. org/10.1016/i.chemosphere.2017.01.045

3. PATEL KS, SHARMA R, DAHARIYA NS, YADAV A, BLAZHEV B, MATINI L, HOINKIS J 2015 Heavy metal contamination of tree leaves. Am J Analyt Chem 6: 687-693. DOI: https://doi. org/10.4236/ajac.2015.68066

4. SERBULA SM, MILJKOVIC DDJ, KOVACEVIC RM, ILIC AA 2012 Assessment of airborne heavy metal pollution using plant parts and top soil. Ecotoxicol Environ Saf 76: 209-214. DOI: https://doi.org/10.1016/j.ecoenv.2011.10.009

5. BARGAGLI R, MONACI F, AGNORELLI C 2003 Oak leaves as accumulators of airborne elements in an area with geochemical and geothermal anomalies. Environ Pollut 124 (2): 321-329. DOI: https://doi.org/10.1016/S02697491(02)00465-7

6. SAWIDIS T, CHETTRI MK, PAPAIOANNOU A, ZACHARIADIS G, STRATIS J 2001 A study of metal distribution from lignite fuels using trees as biological monitors. Ecotoxicol
Environ Saf 48: 27-35. DOI: https://doi.org/10.1006/ eesa.2000.2001

7. LIPPO H, POIKOLAINEN J, KUBIN E 1995 The use of moss, lichen and pine bark in the nationwide monitoring of atmospheric heavy metal deposition in Finland. Water Air Soil Pollut 85 (4): 2241-2246. DOI: https://doi. org/10.1007/BF01186167

8. JIANG Y, FAN M, HU R, ZHAO J, WU Y 2018 Mosses are better than leaves of vascular plants in monitoring atmospheric heavy metal pollution in urban areas. Int $J$ Environ Res Public Health 15 (6): 1105. DOI: https://doi. org/10.3390/ijerph15061105

9. JAMNICKÁ G, VÁL'KA J, BUBLINEC E 2013 Heavy metal accumulation and distribution in forest understory herb species of Carpathian beech ecosystems. Chem Spec Bioavailab 25 (3): 209-215. DOI: https://doi.org/10.3184/ 095422913X13785568683285

10. NOWAK JD HIRABAYASHI S BODINE A GREENFIELD E 2014 Tree and forest effects on air quality and human health in the United States. Environ Pollut 193: 119-129. DOI: http:// dx.doi.org/10.1016/i.envpol.2014.05.028

11. SAWIDIS T, BREUSTE J, MITROVIC M, PAVLOVIC P, TSIGARIDAS K 2011 Trees as bioindicator of heavy metal pollution in three European cities. Environ Pollut 159: 35603570. DOI: https://doi.org/10.1016/i.envpol.2011.08.008

12. BERKI I, RASZTOVITS E, MÓRICZ N, KOLOZS L 2016 The 
role of tree mortality in vitality assessment of sessile oak forests. South-east Eur for 7 (2): 91-97. DOI: https://doi. org/10.15177/seefor.16-14

13. PITMAN R, BASTRUP-BIRK A, BREDA N, RAUTIO P 2010 Sampling and analysis of litterfall. Part XIII. In: Manual on methods and criteria for harmonized sampling, assessment, monitoring and analysis of the effects of air pollution on forests. UNECE ICP Forests Programme Coordinating Centre, Hamburg, Germany, pp 16

14. PARZYCH A, MOCHNACKÝ S, SOBISZ Z, KURHALUK N, POLLÁKOVÁ N 2017 Accumulation of heavy metals in needles and bark of Pinus species. Folia For Pol Ser A 59 (1): 34-44. DOI: https://doi.org/10.1515/ffp-2017-0004

15. BRECKLE SW, KAHLE H 1992 Effects of toxic heavy metals $(\mathrm{Cd}, \mathrm{Pb})$ on growth and mineral nutrition of beech (Fagus sylvatica L.). Vegetatio 101 (1): 43-53

16. DOGANLAR BZ, DOGANLAR O, ERDOGAN S, ONAL Y 2012 Heavy metal pollution and physiological changes in the leaves of some shrub, palm and tree species in urban areas of Adana, Turkey. Chem Spec Bioavailab 24 (2): 65-78. DOI: https://doi.org/10.3184/095422912X13338055043100

17. JONCZAK J, PARZYCH A 2014 The content of heavy metals in the soil and litterfall in a beech-pine-spruce stand in Northern Poland. Arch Environ Prot 40 (4): 67-77. DOI: https://doi.org/10.2478/aep-2014-0039

18. BANKOVIĆ S, MEDAREVIĆ M, PANTIĆ D, PETROVIĆ $N$ 2009 National forest inventory of the Republic of Serbia. Ministry of Agriculture, Forestry and Water Management of the Republic of Serbia, Forest Directorate, Belgrade, Serbia, $244 p$

19. STOJNIĆ S, TRUDIĆ B, GALOVIĆ $V$, ŠIMUNOVAČKI Đ, ĐORĐEVIĆ B, RAĐEVIĆ V, ORLOVIĆ S 2014 Conservation of Pedunculate oak (Quercus robur L.) genetic resources in the Public Enterprise "Vojvodinašume" (in Serbian with English summary). Topola 193-194: 47-71

20. NOVAKOVIĆ AR, KARAMAN MA, MILOVANOVIĆ ILJ, TORBICA AM, TOMIĆ JM, PEJIN BM, SAKAČ MB 2018 Nutritional and phenolic profile of small edible fungal species Coprinellus disseminatus (Pers.) J.E. Lange 1938. Food and Feed Research 45 (2): 119-128. DOI: https://doi. org/10.5937/FFR1802119N

21. TIBCO SOFTWARE INC 2017 Statistica (data analysis software system), version 13. URL: http://statistica.io.

22. DE VISSER PHB 1992 The relations between chemical composition of oak rings, leaf, bark, and soil solution in a partly mixed stand. Can J Forest Res 22 (12): 1824-1831. DOI: https://doi.org/10.1139/x92-238

23. OPYDO J UFNALSKI K OPYDO W 2005 Heavy metals in Polish forest stands of Quercus robur and $Q$. petraea. Water Air Soil Pollut 161 (1-4): 175-192. DOI: https://doi. org/10.1007/s11270-005-3522-5

24. SANTA REGINA I, RICO M, RAPP M, GALLEGO HA 1997 Seasonal variation in nutrient concentration in leaves and branches of Quercus pyrenaica. J Veg Sci 8 (5): 651-654. DOI: https://doi.org/10.2307/3237369

25. WĘGIEL A, BIELINIS E, POLOWY K 2018 Heavy metals accumulation in Scots pine stands of different densities growing on not contaminated forest area (northwestern Poland). Austrian J For Sci 35 (3): 259-281
26. KOVÁCS M, PENKSZA K, TURCSÁNYI G, KASZAB L, TÓTH S, SZÔKE P 1994 Comparative investigation of the distribution of chemical elements in an Aceri tatarico-quercetum plant community and in stands of cultivated plants. In: Markert B (eds) Environmental Sampling for Trace Analysis. VCH, Weinheim, pp 435-442

27. STANKOVIĆ D, MEDAREVIĆ M, KRSTIĆ B, BJELANOVIĆ I, ŠLJUKIĆ B, KARIĆ D, JANJIĆ M 2013 Concentration of heavy metals and stand state of sesille oak (Quercus petraea (Matt.) Liebl.) on Avala mountain (Serbia). Carpath J Earth Environ Sci 8 (3): 59-66

28. STANKOVIĆ D, ŠIJAČIĆ-NIKOLIĆ M, VILOTIĆ D, IVETIĆ V, KARIĆ D, VESELINOVIĆ M 2015 Iron (Fe) content in vegetation cover of the natural protected area Kosmaj, Serbia. Fresen Environ Bull 24 (2a): 626-631

29. ABOAL JR, FERNÁNDEZ JA, CARBALLEIRA A 2004 Oak leaves and pine needles as biomonitors of airborne trace elements pollution. Environ Exp Bot 51 (3): 215-225. DOI: https://doi.org/10.1016/j.envexpbot.2003.11.003

30. SANTAMARÍA JM, MARTÍN A 1998 Influence of air pollution on the nutritional status of Navarra's forests, Spain. Chemosphere 36 (4-5): 943-948. DOI: https://doi. org/10.1016/S0045-6535(97)10152-7

31. STANKOVIĆ D, JOKANOVIĆ D, VESELINOVIĆ M, LETIĆ LJ, JOVIĆ Đ, KARIĆ D 2015 Zinc concentration in woody and herbaceous plants at Kosmaj area, Serbia. Fresen Environ Bullet 24 (11): 3672-3675

32. STANKOVIĆ D, IVETIĆ $V$, OCOKOLJIĆ M, JOKANOVIĆ D, OLJAČA R, MITROVIĆ S 2015 Manganese concentration in plants of the protected natural resource, Kosmaj, in Serbia. Arch Biol Sci 67 (1): 251-255. DOI: https://doi.org/10.2298/ ABS141112031S

33. DEVETAKOVIĆ J, STANKOVIĆ D, IVETIĆ I, MITROVIĆ B, TODOROVIĆ N 2017 The concentration of $\mathrm{Zn}, \mathrm{Mn}$ and Fe in leaves of Ulmus laevis Pall. at Veliko Ratno Ostrvo island (Belgrade, Serbia). Carpath J Earth Env 12 (1): 69-75

34. ŠIJAČIĆ-NIKOLIĆ M, STANKOVIĆ D, KRSTIĆ B, VILOTIĆ D, IVETIĆ V 2012 The potential of different lime tree (Tilia spp) genotypes for phytoextraction of heavy metals. Genetika+ 44 (3): 537-548. DOI: https://doi.org/10.2298/ GENSR1203537S

35. MIN MB 2000 Comparison of phenological characteristics for several woody plants in urban climates. J Plant Biol 43 (1): 10-17. DOI: https://doi.org/10.1007/BF03031030

36. PEKEČ P, ORLOVIĆ S, KATANIĆ M, STOJNIĆ S, DREKIĆ M 2017 Fenološka osmatranja hrasta kitnjaka (Quercus petraea Matt/Liebl.) i hrasta lužnjaka (Quercus robur L.) na području Vojvodine (in Serbian with English summary). Topola 199-200: 11-20

37. MILOŠEVIĆ T, MILOŠEVIĆ N, GLIŠIĆ I, KRŠKA B 2010 Characteristics of promising apricot (Prunus armeniaca L.) genetic resources in Central Serbia based on blossoming period and fruit quality. Hort Sci 37 (2): 46-55. DOI: https:// doi.org/10.17221/67/2009-HORTSCI

38. ORLOVIĆ S, ERDEŠI J, RADIVOJEVIĆ S, OBUĆINA Z, JANJATOVIĆ G 2001 Semenske plantaže hrasta lužnjaka (Quercus robur L.) - osnov za dalje oplemenjivanje u ravnom Sremu (in Serbian with English summary). Šumarstvo 1: 1-9 